\title{
LINNATEEMA VANEMAS RAHVALAULUS
}

\author{
TIIU JAAGO
}

$\mathrm{V}$ anem rahvalaul ei seostu eelduspäraselt linna või linnaelu kujutamisega. Esmalt tingib selle regilaulustiili vanus, mida hinnatakse mitme aastatuhandega (Tedre 2008 [1998]: 425; Sarv 2000: 13-14). Linnad hakkasid aga Eestis kujunema XIII-XIV sajandil (EA 2012: 123). Teiseks meile tuntud regilaulude teemasid ning esitusviise seostatakse põlluharijate elustiiliga (Peegel 1997: 119). Ühtlasi oli Eestis XIX sajandi lõpul - laulude suurkogumise ajal - maaelanike osakaal linnaelanike omast märkimisväärselt suurem: 1897. aasta rahvaloenduse andmetel oli neid vastavalt 81 ja 19 protsenti (Palli 1998: 29). Ja lõpuks: paralleelselt maalt linna asumisega XIX sajandi lõpul taandus ju õieti ka regilaulutraditsioon.

Teisalt on lauludega tegelejatele siiski silma ja kõrva jäänud linnaga seotud vormelid. Näiteks värsid „Loomise” ouna kirjeldusest: Riia poolt oli ristiline / Narva poolt oli naastuline [vt nt H I 5, 69 (173)]; tuleb tuttav ette, et noormees läks Narvast naista tooma [H II 59, 478 (19)]; et „Mareta lapse” laulus leidis hüljatud lapse linnateele läinud naine [H II 57, 424 (7)]. Samas tuleb möönda, et linn ei ole neis lauludes sõnumi seisukohalt tähenduslik ja kõike seda saab laulus öelda ka teisiti. Loomisloo õuna igakülgses kirjelduses võib linnakujundi asemel leida ka ilmakaarte kujundit: lõuna poolt oli lee karva, /koidu poolt oli kurruline,/vesikaare küljed viirulised [H II 2, 200/2 (307)]; Narva asemel võidakse naist tuua ka lihtsalt kaugelt: vend läks kaugelt naista tooma, / ̈̈le soo, üle rabade, / kus pold kuulda kuke häälta, / põdra lapse nutu häälta [E 6608 (9)]; Mareta-laulu hüljatud laps võidakse leida ka karjateelt [nt H II 1, 212 (314)].

Vanemaid rahvalaule analüüsides võib sattuda ka sellisele linnateema arendusele, mis paneb juurdlema maa ja linna omavahelise seotuse üle laulikute külakeskkonnas. Sellele on juhitud tähelepanu mängulauludega seoses (Tampere 1958: 14; Mirov 1998: 41-43). Kuid seda võib kohata teistegi laululiikide puhul. Näiteks Karuse kihelkonna Petaaluse küla lauliku Liisu Krebsi repertuaarist pärit pulmalaulus julgustatakse noormeest: ärgu ta kartku, et peab pruudile riiete ostmiseks raha kulutama - neiu teeb kõik ise. Riiete valmistamiseks on ta töövahendid saanud linnast:

Lihulast tuob lõime lõngad,

Absalust tuob kuue lõngad.

Ta tuob niied Miitu linnast [---]

Soomelinnast suure sua,

Pieterborist pika pooli.

H II 2, 180 (285).

Mida enam laule „linna” püüdva pilguga vaadata, seda enam selgub, et linnakujundeid ei olegi lauludes nii vähe. Osalt on need seotud laulutüübiga („Riia rikkumine”), osalt kinnistuvad teatud motiivide juurde (imelik maja; 
oleks see mees minule). Üldjoontes seostuvad need aga kindlate teemadega, milles domineerivad kosjad ja kaubandus (seda ka omavahel põimudes) ning nekrutiks värbamine.

Alljärgnevas artiklis keskendun linnateema esinemisele regilaulus. ${ }^{1}$ Alusmaterjaliks on Eesti regilaulude andmebaasi (http://www.folklore.ee/regilaul/) sisestatud tekstid. Andmebaas hõlmab Jakob Hurda (H), M. J. Eiseni (E) ja Eesti Üliõpilaste Seltsi (EÜS) rahvaluulekogudes leiduvaid regilaulutekste, mis pärinevad XIX sajandi lõpust, XX sajandi algusest. Andmebaasist materjali otsimisel kasutasin otsisõnu („linn” < „linna”; otsitavate linnade nimed). Kõrvale aga jätsin „liina” otsinguga kuvatud, peamiselt setu ja kagueesti laulud, kuna need erinevad siinkäsitletuist nii temaatiliselt kui ka vormelikeelelt sel määral, et vajavad omaette lähivaatlust. Täpsustavate andmete otsimisel (näiteks laulutüübi „Mareta laps” variantide võrdlemisel) on kasutatud lüroeepiliste laulude teaduslikku väljaannet „Eesti rahvalaulud” I osa (ER 1926). Mõlemad tekstikogumid tuginevad Eesti Rahvaluule Arhiivi kogudele.

\section{Uurimistaust}

Käsitluse eelduseks on, et regilaulus peegelduv suhtumine linna rajaneb laulutraditsiooni valdava kogukonna üldisele arusaamisele linnast. Üldjoontes võib linnakujundite kasutuses näha pigem kas vormelikesksust (need ei kõnele kuigi palju linnast endast, sest esil on kujundi muud, sh kõlafunktsioonid) või teemakesksust (millest nähtub ka linnale omistatav tähendus laulus kujutatava maailma seisukohalt). Piir mainitud linna kujutamis- või esinemisviiside vahel ei ole mitte alati üheselt määratletav. Lauluanalüüsis lähtungi mitte niivõrd kujundite liigitamisest ühte või teise kategooriasse, kuivõrd küsin, kuidas avaneb linnateema vormelite kaudu ja kuidas teemast lähtuvate küsimuste kaudu. Vormelitest (nt alliteratsioonivormelid Riia - rist; Narva naast; Narva - naist; läbi-Lihula) lähtuv vaade võimaldab enam keskenduda laulu kujundikeelele ja selle kaudu liikuda maa ja linna omavaheliste seoste tõlgendamisele. Linnateemast lähtudes saab küsida, milliseid linna ja maa omavahelisi seoseid regilauludes kujutatakse. Nimetatud lähenemisviisid asetuvad üldisemalt kahte teoreetilisse plaani: vormelikeele ehk regilaulu stereotüüpsuse uuringud; tematiseerimine ja sellega seotud pärimusliku ajaloo uurimine.

Regivärssides esinevate sõnade püsiseoseid hakati süsteemselt uurima 1960. aastatel, eesmärgiks mõista suulise traditsiooni stereotüüpsust ja varieeruvust lauluosade tasandil (Laugaste 1962: 27; Tedre 1964: 8). Selle uurimistraditsiooni raames eristas Udo Kolk (1962) värsist väiksema üksusena püsivad sõnaseosed, mida ta nimetas vastavalt alliteratsioonivormeliteks (samakõlaga seotud sõnad värsis) ja parallelismivormeliteks (üksteisega kokkukuuluvad või üksteist esilekutsuvad kordussõnad paralleelvärssides). Rahvalaulu kinnistunud sõnaseoste ehk vormelite uurimine 1930.-1960. aastate Põhja-Ameerika ja Lääne-Euroopa folkloristikas kujundas oluliselt suulisuse uurimist üldiselt (Foley 1988: 41-42). Erinevalt eesti teadustraditsioonist

${ }^{1}$ Tänan Eesti folkloristide talvekonverentsist „Folkloor linnas ja linnast” (28. II-1. III 2013) osavõtnuid huvi ja asjakohaste kommentaaride eest, mis aitasid kaasa selle artikli valmimisele. 
ei otsitud siin vormeleid kirjapandud tekstidest, vaid analüüs rajanes suulisel esitusel, kus vormelit käsitleti esituse ühe komponendi ja loomisvõttena (Lord 1997 [1960]: 13-14, 17; Rubin 1997: 9). Neid, eraldiseisvalt kujunenud vormelikäsitlusi ühitas Liina Saarlo, viidates nii esituslikele kui ka tekstikorpuste analüüsist tulenevatele aspektidele. Ilmnes, et korduste arv (kvantiteet) ei taga iseenesest sõnaseoste tajumist vormelina, oluline on ka sõnaseostest tekkiv tähendusväli (Saarlo 2001: 293). Et vormelit käsitleda suulise traditsiooni loomuomase tunnusena, sellele on ka vastuväiteid (Scollon, Scollon 1995: 20). Sellegipoolest nõustun regilaulu definitsioonidega, kuhu kuulub värsimõõdu, algriimi ja parallelismi kõrval ka viide traditsiooniliste vormelite, kujundite ja teemade kasutamisele, nagu seda määratleb Mari Sarv (2000: 15).

Teemakeskse lähenemise puhul tuleb esile küsimus, mil määral saab laulude kaudu aimu laulikute argielust, suhtlusviisidest, hoiakutest jms, mis on huvipakkuvad argielu ajaloo vaatepunktist. Rahvaluule ja ajaloo omavaheliste seoste väljaselgitamisel on taas märkimisväärne uurimisajalugu. ${ }^{2}$ Eesti teadustraditsioonist lähtudes on siinkohal olulised kaks aspekti: millega seoses ja kuidas on uuritud rahvalaulude ajaloolist konteksti; mil määral saab laulude kaudu uurida laulmisaegset sotsiaalajaloolist tausta. Rahvalaulude asetamine ajaloolisse konteksti on üldiselt põhjendatud laulude tekke ja kujunemise asjaolude väljaselgitamisega. Ajaloosündmuste ja olukordade raami on enam paigutatud lõppriimilisi laule (Kokamägi jt 1970; Rüütel 1977; Tedre 2003 [1954]: 41-60; Lintrop 2006). Neile töödele on iseloomulik, et ajaloosündmuste kõrval on oluline koht ka tolleaegse kirjanduse analüüsil. Allolevas uurimuses on aga keskne koht mitte niivõrd ajaloosündmustel või intertekstuaalsusel eesmärgiga välja selgitada laulude tekke- ja kujunemiskeskkonda, kuivõrd laulus kajastuval linnakuvandil. Analoogilise küsimuse on esitanud Kristiina Ehin artiklis „Naise identiteedi muutus pärast Esimest maailmasõda - rahvalaul kõneleb" (Ehin 2003). Selles töös on esil inimene ja tema hoiakute teisenemine muutuvas keskkonnas. Selline lähenemisviis eeldab tõlgendust ja sellest tulenevalt tõlgendusraami loomist. Ehin valib selleks pärimusliku ajaloo vaatepunkti: kuidas lauludes peegelduvat ajalootunnetust mõistab ja mõtestab uurija (Ehin 2003: 160-161). ${ }^{3}$ Refereerin tema uurimust lähemalt, kuna seegi tegeleb linnateemaga. Analüüsitavas lõppriimilises laulus jutustatakse naise identiteedi muutumisest, kui naine läks talust linna elama. Ilmneb, et kujutlus linnanaise elust koondub mõistesse ,jõudeelu”. See kujutab endast linnaelu suurimat pahet ja ühtlasi vastandub talunaise elule. Jõudeelu väljendub laste vähesuses - naised ei tegele laste kasvatamisega endisel määral -, kodust välja tööle minekus ja moraalitus käitumises (Ehin 2003: 166-169). Pärimusliku ajaloo vaatepunktist on uurija fookus laulude tõlgendamisel seega hoiakute, seoste, hinnangute leidmisel. Käesolevas artiklis keskendungi linnateema ja sellega seotud vormelite esiletoomisele. Edaspidi on võimalik saadud andmeid täpsemalt tõlgendada sotsiaalajaloolises või kultuuriajaloolises kontekstis.

Enne tekstianalüüsi juurde asumist on vajalik peatuda sõna „linn” etümoloogial. Selleks on vähemalt kaks põhjust: miks nimetatakse linnaks kohti, mis seda administratiivses mõttes ei ole (nt Lihula linna); mida tähendavad

${ }^{2} \mathrm{Vt} \mathrm{nt}$ teadusvaldkondade omavaheliste põimumiste ja eemaldumiste periodiseeringut Burke 2004; autobiograafilise jutustamise folkloristlikku uurimist Titon 1980; Hopkin 2004; rahvaluule tõlgendamist maa või piirkonna ajaloo raamistikus Dorson 1986.

${ }^{3}$ Üldiselt on pärimusliku ajaloo uurimisviisi rakendatud mälestuste uurimisel (vt ülevaadet Jaago 2006). 
värsid ema, mu lihane linna, / isa mu vahane valli $?^{4}$ Etümoloogia sõnaraamatu andmetel on tegemist läänemeresoome tüvega, mis tähistab linnust, lossi. Lihulas on tõesti XIII sajandist pärit linnuse varemed. Kaitserajatisena sobitub linn(us) funktsiooni ülekande puhul metafoorselt tähistama vanemate ja pere toetust.

\section{Linnad regilaulus: vormelitest lähtuv vaade}

Linnaga seotud kujundite esmaotsingus, nagu ka vormelikeele analüüsis, lähtusin linnanimedest. Linnanimesid võib kohata värssides, kus kasutatakse alliteratsioonivormeleid (Riia - rikas ${ }^{5}$ )või parallelismiseoseid (Riia/Tallinn ${ }^{6}$ ). Viimasel juhul moodustuvad linnade (või ka maade, maakondade) nimedest paralleelsõnade rühmad, mis võivad, kuid ei pea viitama reaalsele maakaardile. Linnanimede koondumine paralleelsõnadeks (ehk paralleelvärsside kordussõnadeks) seletub nn leksikaalse ühtsuse seadusega, millest pikemalt on kirjutanud Juhan Peegel: „Poeetiliste sünonüümide süsteemis on silmapaistev tendents kasutada alussõna teisendavas sünonüümidereas leksikaalselt ühte kuuluvaid, s.o. ühte tüüpi sünonüüme. Selle leksikaalse analoogia seaduse tekkimine on üsnagi arusaadav, sest sel kombel on kergem sünonüümideahelat meeles pidada, küllap oli ka kergem värsimõõtu sobitada" (Peegel 1997: 104). Seega linnanimest alussõna „kutsub” paralleelvärsis esile teise linna nimetamise, mistõttu tavageograafia seguneb kujundiilma-kaardiga. Riia, Narva või mõne muu linna esinemine ei viita üheselt nimetatud linnale, vaid ka näiteks linnale kui sellisele üldiselt, ka orientiiridele maakaardil (nagu kubermangukeskused Riia / Tallinn) või tunnustegevustele (nt riigiinstitutsiooni tegevustega seostuv Moskva nekrutilauludes).

Tutvustan esmalt linnanimedeotsinguga seotud tulemusi, lähtudes osalt esinemisarvukusest (esikohal on Riia), osalt nende paralleelsõnadest lähtudes (Riia/Tallinn). Otsisõna „Riia” kohta kuvati andmebaasis 1647 tulemust (ehk lauluteksti). Kuigi temaatiliselt koonduvad need värsid suhteliselt selgepiiriliselt kosja-, sõja- ja kaubandusteemade ümber, kohati omavahel põimudes, on värsid märkimisväärselt varieeruvad. Reeglina seostub laulus Riia rikkuse, aga ka paremaks või „kõrgemaks” pidamisega. Näiteks toob veli Riiast rikka naise või uppunud vend oli kallis - maksis Riia linna; sõsaral on palju kosilasi, $\mathrm{mh}$ Riia rü̈utlid või kiidetakse ilmarikast isa, kel poeg on Poolamaa kuningas, tütar Riia neitsikene [E 8623 (19); E 8260 (42); E 5389; E 7640 (8)].

Riia ja Tallinn satuvad paralleelsõnadena märkimisväärselt kokku „Riia rikkumise" laulus. Kuid sama sõnaseost võib kohata laulmisega seoses. Näiteks lauluhääle saamislugudes, kus laulikmina on viidud Riiga ristima/Tallinna nime panema ning sellest on ta saanud hõbedase lauluhääle [E 7848 (4); E 8049 (38); E 9323 (13); E 15101 (3)]. Endine lauluhääl aga oli nagu Rootsi pilliroog, / Tallinna paras pasun; ka Viiburi vile [E 10633 (14); E 7692 (2); E 7827 (1); E 13671; E 9413 (89)]. Või öeldakse hoopis, külas lauldakse nagu Riia roopilli, / Tallinna tasane pilli [H II 54, 310 (21)]. Riia ja Tallinna seotust

${ }^{4}$ Ema mu lihane linna, /isa mu vahane valli, /velle tugev tuulevarju,/sõtsi sirge selja varju. - E 51289 (7). Vrd E 52492 (49); EÜS VIII 1618 (133).

${ }^{5}$ Riiast saavat rikast naista - E 8623 (19); Rikas Riia härrakene - E 7150 (10).

${ }^{6}$ Nii kui Riia ruugupilli, / Tallinna tasane pilli - H II 54, 310 (21). 
kaubandusmaailmaga kohtab „Kaevul kosija” laulus, kus oodatavaks noormeheks on Riia rikas poiss, / Tallinna rahataguja, / Narva naasto kirjutaja, / Võnnu võtteme vedaja [E 25453 (11); H II 55, 825 (15)].

Vormelitest on nähtav, et neis sõnaseostes juhib sõnavalikut Riiaga seotud sõna kõla (rikas, ristiline, riidelema), millega teatud juhtudel haakuvad paralleelväljendid (Narva - naastuline; Tallinna tappelema). Kirjeldatud juhtudel on tegemist väljakujunenud alliteratsiooni- ja parallelismivormelitega, kus linnanimed esinevad koos samakõlaliste omadus- või tegusõnadena ja need ei ole väljavahetatavad muude linnanimede vastu. Ühtlasi võivad sellised püsivad sõnaseosed ilmneda erinevate nähtuste kirjeldamisel. Näiteks artikli alguses toodud õuna kirjeldusele lisaks kasutatakse samu vormeleid Riia ristiline ja Narva - naastuline vennanaise kirjelduses: vennanaisele ei sünni rinda Riia ristid ega Narva naastud [E 8078 (62)].

„Tallinna” märksõnaotsingul kuvati 299 laulu. On eripärane, et Tallinnaga seotud värssides leidub sotsiaalsete teemade kirjeldusi. Noormehed kavatsevad tööd teha nii, et nad saavad pärast kõrtsi minna ja siis ringi käia kui raehärrad, Tallinna parajad mehed [E 11487 (6)]. Lauldakse, et noormees ei taha teha kõiki töid, sh neid, mida pakkusid teha Tallinna sulased [E 17819 (7)].

Peterburi (26 laulu) seostub eelistatavalt kaubateemaga, mis kohati põimub kosjateemaga. Näiteks noormees ehk petis peiu lubab tuua Peterburist / Rootsist sinist siidi ja punast poordi, ent tõi piitsa ja rooska [H II 3, 629 (219)]. Mardilaulus küsitakse, kas võib tuppa tulla, sest käidud tee oli pikk ja nüüd tuppa tulles ehk hukkan ummiskingad, Tallinnast toodud tasased saapad, Peterburist toodud pikad püksid [EÜS II 569 (81)]. Peterburiga seostub ka nekrutiteema: noormehele oli määratud kodus tööde tegemise asemel käia sõja(mehe) tee ehk teeda pikka Peterburi [EÜS IX 1130 (80)]. Näiteist ilmneb taas suundumus omadussõna ja linnanime häälikulisele kooskõlale (pikk - Peterburi), kusjuures neis sõnakõlale rajanevates püsiseostes ei pruugi mitte alati täiendsõna liituda linnanimega (nagu antud näidetes: pikad püksid Peterburis; pikk tee Peterburi). Kahes 1878. aastal Kolga-Jaanis kirja pandud laulus kõneldakse lauluhäälest, millega saab Narva naiste vasta, / Peterburi poiste vasta [H; Kolga-Jaani 3, 42 (43); H; Kolga-Jaani 3, 146 (119)]. Kose kihelkonnast 1887. aastal üleskirjutatud „Loomises” kõneldakse ilmalinnust, kes tuli linnast: tantsis ümber Tallinna linna, /lendas ümber Riia linna, / piiras ümber Peterburi [H II 16, 137 (172)]. Peterburi üks nimevormidest Piedari leidub Kuusalu lauludes: minategelane tõi endale linnast naise - Helsingist ella kulla, / Piedarist pienikaise [H II 34, 678 (357); EÜS VII 2065 (365)].

Moskva (25 laulus) seostub reeglina sõtta või sõjaväkke kutsumisega ja haakub sellisena regilaulus enam tuntud värssidega Venemaale/Poolamaale kutsumise kui ka siirdevormiliste laulude Prantsusele ja Ponapartile viitamisega. Näiteks nekrutilaul Põlvast, mis on üles kirjutatud 1894. aastal:

[Sõtta] viijäs sirge vele, viksi viijäs Venemaale, punapõski Poolamaale [---]

Mõni saa liiva, mõni liina, mõni Pihkva peräle, mõni Moskva morole.

E 13391. 
Üksikutel juhtudel leidub Peterburi/Moskva värsiseoseid vangilauludes [mis viga linnas vangis olla - Peterburis ollakse kuninga silma all, Moskvas on moosekandid - nagu on Väike-Maarjas 1890. aastal kirja pandud laulus ( $\mathrm{H}$ II 12, 54 (30)], Moskvat üksi ka härrasrahva söögi-joogi kirjelduses: härraste laual on limonaad ja kohv, põrsapraad ja mh Moskva jahu, öeldakse 1891. aastal Ansekülast üles kirjutatud laulus [H, Mapp 133 (5)]. Juhuslikult võib Moskva sattuda kosjateemalise laulu linnade loetellu. Näiteks Moskvast saadakse moodne naine, või kodust kaugelt kositud ja kaunilt riietatud pruudi kirjelduses on neiu ehitud Helsingis, / sõrmused vahetatud Sõrves, / Moskvas mundrisse pandud, / Tallinnas tanutatud, / Peterburis põlled ette pandud [EÜS IX 89 (86); E 13908 (15)].

Kaugematest linnadest esineb lauludes Vaasa, mis seostub väljarände teemaga. Andmebaasist leitavad kaks varianti pärinevad Harju-Madise kihelkonnast ja on üles kirjutatud vastavalt 1889. ja 1895. aastal [H II 15, 662 (85); E 15714 (235)]. Linnanimesid sisaldavate paralleelvärsside loendis võib kohata ka ilusat Helsingit, ja vile-sõnaga seostuvat Viiburit. Näiteks imeliku maja motiivis esinevad need Riia ja Pärnu paralleelsõnadena:

On see rikas Riia linna

või oo see päris Pärnu linna

või oo see ilus Helsingi

või oo see vilest Viiburine.

E 42921/2 < Pöide khk, Tornimäe - M. Pallas (1902).

Eesti linnadest on regilaulus enam kasutatavad Narva (974 teksti) ja Pär$n u$ (745 teksti). Narvast naise toomine on üks levinumaid motiive, mis selle linna nimega seostub. Ent paralleelsõnade lisandus hajutab geograafia ja toob esile linna kui niisuguse:

See tahab naista Narva maalta, Narvast naista ja Riiast rikasta ja Peterborist peenikesta<smiles>[AlH]</smiles>

Narvast (s.o linnast) ei soovitata naist võtta. ${ }^{7}$ Ent kust siis?

Ära võta naista Narva maalta, ära võta Riiast rikasta, Peterborist ei peenikesta

[---]

Võta naene enne nähtud, enne nähtud, karjas käitud.

Sihi aga neiu sirbi päälta ja vahi vikati löelta

H III 7, 843/6 (6) < Vändra khk - M. Michelson < Mari Ärm (1890).

${ }^{7}$ Ka vanasõnade hulgast võib leida: „Narr, kes Narvast naise võtab, loll, kes linnast lehma ostab" (tüübi nr 7386). 
Üldjoontes viitab Narva regilaulus geograafiliselt kaugele kohale. Eeltoodud näidetes Narvast naine ongi ju ühtlasi nii linnast toodud (saks, rikas „teine”) kui ka kaugelt toodud (mitte oma külast pärit). Kuid Narvaga seostub teisigi näiteid, kus lauliku asukohast vaadatuna viidatakse nn kaugele kohale (seda regilaululikult mitmesuunalises mõõtmes): neiu läheb Riiast vett tooma, taga Narva allikast seda ammutama; või läheb laulikmina arsti otsima Tallinna targa juurde, taha Narva naiste juurde [EÜS III 289 (25); H II 28, 847 (1)]. Kõikjale-kaugele suunatust kohtab veel lauliku mõjuvõimu kirjeldustes, kus laulik saab oma sõnaga üle mere meeste vastu,/taga Narva naiste vastu, / üle Poola poiste vastu [EÜS III 315 (33); vrd H III 7, 88 (44)]. Ent neis värssides põimub kaugussuhe kogukonnasuhetega, sest linnanime näikse esile kutsuvat esmajärjes paralleelsõnade seos mehed - naised ja seejärel alliteratsioonivormel naised - Narva. Analoogiline seos mehed - naised - poisid, kus naised seostub Narvaga, leidub kosjamotiivides (nt kulla põlemine; must naine):

Ei saand vetta neiu pesta,

kastet käo kasida,

lund ei luige loputada.

Mehed tõid meresta vetta,

poisid tõid punajõesta

naesed Narva allikasta.

Siis sai vetta neiu pesta [---]

H III 7, 545 (10) < Põltsamaa khk - K. Leht (1889). ${ }^{8}$

Neis näidetes on silmahakkav Narva seostamine veega, kuid selle seose tagamaa nende andmete põhjal siiski ei avane. Vormelite võrdlusest lähtuvalt võib eeldada, et veega seotud kujundites ei juhi sõnavalikut mitte Narva, vaid naine..$^{9}$ Seega on kujundis esil kogukond, mitte koht.

Narva ja Pärnu kohtuvad paralleelsõnadena „Rikka härja ja vaese varese” laulus, kus vaese mehe tapetud varesest sai nahk Narva sundijalle, / pea Pärnu pealikulle [E 11788 (8), vrd H II 28, 389 (54); H III 5, 529/30 (14)]. Üldiselt kohtab aga Pärnut algriimiseostes: Pärnu - päev (seda nii ajaühiku kui ka päikese tähenduses), pärg, pea (pä̈̈), pealt (pä̈̈lt). ${ }^{10}$ Sageli on päeva paralleelsõna kuu (seda nii taevatähtede tähenduses kui ka ajamääratlustena), mistõttu toob Pärnu paralleelsõnaks Kuramaa või mõne teise $k$-ga algava sõna. ${ }^{11}$ Määratletud kohana mõjub Pärnu nekrutilaulus, kus liisu alla sattunud noormees ütleb oma staatuse kohta: nüüd on ta, vaene, Pärnu valli peal (see on Tõstamaalt 1882. aastal kirja pandud tekst) [E 638]. Riia paralleelsõnana seostub ka Pär$n u$ rikkusega: neiu ei tohi kiigelt kukkuda, sest kes tema eest maksab, kui pea mulle maksab Pärnu linna, / rinnad maksavad Riia linna. ${ }^{12}$ Pärnu iseseisvalt rikkusele ei viita.

\footnotetext{
${ }^{8}$ Vrd H II 26, 1049 (1); E 11218 (5); E 13910 (17); EÜS 399, 261 (76).

${ }^{9}$ Näiteks vihma välja kutsuvas Viljandimaalt kirja pandud laulus seostuvad sõnad: naised - Narva; poisid - Poola (naise joova Narva vetta / poisid - Poola allikasta): E 51912 (2).

${ }^{10}$ Kuu tõusis kura mäesta, / päe Pärnu sillasta - E A 803 (12); Iga päe Pärnu härrad,/ iga reede Riia härrad - H II 59, 642 (9b); Panin pähe Pärnu pärja - H II 59, 623 (1); Alt me lääme Aillu linna, / päält me lääme Pärnu linna - H R 5, 60 (12).

${ }^{11}$ H I 5, 257 (11); E 6770 (24); E 7178 (39). Kui neid värsse laiendatakse, võib lisanduda kolmaski koht: Kuu tõusis Kume jõesta,/agu Narva allikusta, / päev Pärnu läteesta - EÜS III 404/5 (96).

${ }^{12}$ EÜS VIII 1006 (9); vrd Pea mul maksis Pärnu linna, / jala aga tallad Tallinna linna-
} 
Eeltoodud näidetest nähtub ikka ja jälle, et linnanimed seostuvad teatud omaduste või tunnustega linnanimede häälikulise kõla kaudu. Linna asukohast (geograafiast) tulenev linna nimetamine on kas tagaplaanil või isegi mõistetamatu. Kohalike linnade mainimine (sh siirdevormilistes lauludes) võib aga siiski viidata koha konkreetsusele, nagu näiteks mõnedes Haapsaluga seotud tekstides. Haapsaluga seotud laule oli kokku 11, kusjuures isegi sellest väikesest lauluhulgast tulid esile nii teemaringid - kosjad, kaubandus, nekrutiks värbamine - kui ka heakõlaseos: ja sina rikas Riia linn, / ja sina auusa Haapsalu, / ja sina pitka Peterburki, / ja sina muidu Moskva linn [EÜS III 720 (12); vrd H II 41, 207 (12)]. Kohakonkreetsuse juurde tagasi tulles: näiteks kirjeldab laulu minategelasest noormees: läksin linna liisu alla ja jõudes Haapsalu linna, läks ta Aki kõrtsi [EÜS VIII 1389 (95)]. Laul on üles kirjutatud 1911. aastal Kuusalust, ent päritolukohana viidatakse Hanilale. Lääne-Nigula kihelkonnast 1912. aastal üles kirjutatud laulus sõitis noormees Haapsalu linna sisse, sidus hobuse Ärbe poe posti külge ja ostis poest siirupit, viirukit ja 10 naela koogitainast [EÜS IX 435 (46)]. Kuigi ka neid näiteid iseloomustab sama teema: kaubandus, nekrutiks värbamine, on aimatavad Haapsalu kui konkreetse linnaga seotud kohad, mis ärgitavad küsima Aki kõrtsi ja Ärbe poe olemasolu kohta. ${ }^{13}$

Kohalikest paikadest silmahakkav on Lihula kasutus (143 laulus). Lihula ei ole Riia, Tallinna, Narva või Pärnuga võrreldav linn, ent Lihula linna on vormelina laulutraditsiooni kinnistunud (esinedes 81 laulus). Selles tõigas võib määrav olla nii linna etümoloogia kui ka seos linnusega. Lisaks tuleb esile, et eriti kinnistunud on see vormel imeliku maja motiivis. Näiteks Haljalast 1888. aastal kirja pandud laulus:

Kas see on Lihula linna

või on see rauda Rakvere või on keiseri kiriku?

H II 9, 634 (24).

On iseloomulik, et selles laulumotiivis paralleelvärsside linnad vahelduvad, nagu eeltoodud Virumaa näites Rakvere, Muhu laulus on Lihulale lisatud Kuressaare, Pärnu, Tallinn, Paide ja Kärdla; Läänemaal lauldakse Lihula linna paralleelina Haapsalu alevist ja Keila kirikust; Kuusalust üles kirjutatud laulus seostatakse Lihula linna ja Keila kiriku; Viljandis lisatakse neile veel Paide linna jne, ent Lihula on neis seostes püsiv [H II 6, 637 (19); H II 2, 238 (346); H II 34, 725 (431); H III 25, 674 (10)]. Teine Lihula püsiseos on naisevõtukirjeldustes, kus tee linna (olgu Narva ja Peterburi) käib läbi Lihula (40 laulu), nagu näiteks kahes järgmises, Läänemaalt üsna kaugel asuva Virumaa laulus, üles kirjutatud Lüganuse (1890) ja Viru-Jaagupi (1889) kihelkonnast:

\footnotetext{
H II 17, 754 (117).

${ }^{13}$ Aki (Akki; Haki) kõrts asus aadressil Karja 24. Hoone ehitati 1779. aastal varasema hospidali kohale. See oli Laatsareti kõrts, mida „1791. aastal kutsuti juba Haki kõrtsiks”. Ärbe on ilmselt viide poele, mis asus hoones aadressil Karja 14. Selle puumaja ostis kaupmees Carl Ferdinand Erbe 1848. aastal. Kuigi ta müüs selle järgmisele kaupmehele, A. C. Hoffmannile 1857. aastal edasi ja 1868. aastast oli majas hoopis telegraaf, eeldan, et kaupmees Erbe nimele viitab laulu Ärbe. (Rahvusarhiivi Kinnistute register: http://www.eha.ee/ labs/kinnistud/.)
} 
Siis mine Narvast naista tooma, taga Narva teista puolta, mine läbi Lihula

H II 3, 606 (149).

Siis mene Narvast naista tooma,

Peterburist teista poolta, mene siis läbi Lihula

H II 10, 485 (249).

Kohaliku repertuaari näiteks on aga taas, nagu Haapsalugagi seoses konkreetsed kohad Lihulas. Näiteks Muhu laulus kosjasõitu kirjeldav minategelane selgitab: läksin läbi Lihula, /jõudsin Jaani kõrtsi ette. ${ }^{14}$ Küllalt levinud seos on ka Lihula laat, mis ühitab endas alliteratsiooni-vormellikkuse ja sotsiaalajaloolise reaalsuse, kuna Lihulas kui Lõuna-Läänemaa ajaloolises keskuses laadad toimusid.

Toodud näidetest tuleb esile, et linnanimed esinevad värsis heakõla arvestavalt, mistõttu saab rääkida linnanimedega seotud alliteratsioonivormelitest (Riia - rikas, riidlema, rist; Narva-naist, naastuline; Peterburi-pikk, piiras; Helsingi - ilus; Viiburi - vile). Paralleelvärsid hajutavad linnade tõsielulise geograafia ja toovad esile linna kui kujundi (ruumi mitmesuunalisus, viide teekonnale, maa ja linna elustiili vastandus vms).

\section{Linnaga seotud tegevused ja hoiakud - pärimusliku ajaloo vaatepunkt}

Linna kui keskkonna kujutamise otsingu aluseks oli märksõna „linna” (2894 laulu). Kuvatavad tekstid rühmitasin teemade järgi. Teemaanalüüsist lähtuvalt tuleb ennekõike esile laulus kujutatava keskkonna sotsiaal-majanduslik taust, vähesel määral loodus- ja linnakeskkonna vastandlikkus või isegi võõrandumine. ${ }^{15}$ Teemast lähtuv vaade lauludele toob ühelt poolt esile linnaga seostuvad teemavaldkonnad: kaubandus, linna ränne ja ettekujutus tüüpilisest linnainimesest ning -elust, nekrutiks värbamine. Teemaesituste raames joonistub välja linna välisilme (tornid, lipud, „uulitsad”, aga ka linna juurde kuuluvad sadamates randuvad laevad). Teisalt jaotuvad nimetatud teemad vaatleja hoiakutest lähtuvalt kaheks: linn kui külale vastanduv, võõristust tekitav keskkond, ja linn kui loomulik osa külainimese elust. Hoiakutest lähtuv vaade ei kattu teemavaatega, sest ühte ja sama teemat võidakse esitada vastandlikul viisil.

Esiletulevalt vastakaid hoiakuid esindav teema seostub kaasavalikuga („kauplemisega”, leidmisega) linnast. Linn võib selles kontekstis olla abstraktne kauge paik (kaugele kaubeldi, linnaje lükati), mida konkreetsete nimetustega kinnitatakse (tõugati taha Tartu, Prantsuse rajale), tähistamata tõepoolest

${ }^{14} \mathrm{H}$ II 65, 113 (7). Jaani kõrts asub Lihulas Tallinna mnt 8, kus on kõrts olnud vähemalt XVIII sajandi lõpust alates. (Rahvusarhiivi Kinnistute register: http://www.eha.ee/labs/kinnistud/).

${ }^{15}$ Näiteks Läänemaalt üles kirjutatud paar siirdevormilist laulu lindude puuripanemisest ja linna saatmisest: H II 2, 243 (349); H II 17, 606 (8). 
geograafiliselt määratletud kohti. ${ }^{16}$ Sama laulu minategelane küll kinnitab, et ta sai niiviisi rikkale mehele, kuid ta ei ole sellega rahul: mees on halb ja naine igatseb oma lähedasi: kas olin isale kurja, / või olin emale valju, / et mind kaugele kaubeldi [H I 2, 685 (8); vrd EÜS X 2279 (87)].

Võib küsida, kas linnast pärit kaasa on igal juhul võõras? Ilmneb, et regilaulutraditsioonis leidub kirjeldusi neutraalsest hoiakust kahetsuse ja hukkamõistuni. Näiteks mehe vaatepunktist esitatud laulus on linnast pärit naise toomine oma koju lihtsalt tõik, millele hinnangut ei anta: minategelane läks linna herneste ja linnastega kauplema ning tõi sealt endale ühtlasi naise $[\mathrm{H}$ II 57, 414 (2); vrd H I 4, 12 (12); H II 1, 312 (470); E 9964 (2) E 10967 (24); E 24038 (12)]. Või kardab linna kauplema läinud ja sealt naisega tagasi tulnud noormees oma kaasat kodustele näidata, ent vanemad julgustavad poega naist tuppa tooma [EÜS X 1690 (267); vrd E 9561 (2); EÜS IX 1057 (171)]. Neutraalsest hoiakust ei saa aga juttugi olla, kui laulikmina-noormees ähvardab: kui ema ei luba tal meelepärast naist võtta, läheb ta linna, mis on täis litsi latsi ja kus ta on siis uoora hulgas [H II 42, 256 (3)]. Neiu vaatepunktist hurjutatakse linna naist otsima läinud noormehi väitega, et linnast saab ainult litsi [E 23113 (5)]. Linna tööle läinud noormeest jääb neiu siiski igatsema: linna läks mu linnukene [---] tuleks ta ise kojugi, et ei jääks linna risuks [H I 1, 261 (155); E 10840 (4); E 54323 (24)]. Linna läinud neidu võidakse haletseda - miks ta ometi läks litsiks linna rü̈̈telile [E 14780 (3)].

Regilauludes ilmnev eitav hoiak linnanaise suhtes ei ole küll ainuvõimalik, ent on siiski silmahakkav. See tuleb esile ka kaugemate seoste kaudu. Näiteks lisaks eeltoodud näidetele iseloomustatakse linna kui kohta, kus hulguvad litsid [E 45707 (14). Vrd H I 7, 569 (11)] - sellist hinnangut külatüdrukute kirjelduses ei ole. Samuti leidub lauludes hoiatust: ärgu naine naergu teise naise üle, sest naerja tütred võivad kasvada linna litsiks [H I 5, 63 (150)]. Märkimisväärselt palju kohtab vormelit linna litsi sõimus (nt kurja mehe pöördumises naise poole), hoolimata sellest, et see naine ei seostu linnapäritoluga [H II 40, 1002 (93); EÜS X 2193 (31)]. Põhjendusi sellele hoiakule ei esitata. Kaudselt, näiteks õpetussõnadest: ära kosi linnanaist, kosi neiu, keda oled enne näinud, keda oled näinud talutöid tegemas, [H III 7, 843/6 (6)], võib järeldada, et linnast (kaugelt kositud) neidu ei tunta ja olemasoleva ettekujutuse kohaselt soodustab linnaelu kõlvatute elukommete omandamist.

Vastupidiselt eelkirjeldatud vaenulikule hoiakule linnanaise suhtes võib lauludest leida ka linnaihalust. Näiteks unistab laulu peategelasest neiu kaugest ja rikkast kaasast, et elada siis emanda viisi, / pidada põlve proua viisi, / sü̈̈a saia saksa viisi [H II 57, 416 (3), vrd E 51839 (7)]. Lauludes on olemas sõnum, et linna läinud neiust on saanud ilus emanda [E 7723 (1); E 10562 (9)].

Kaasavalikuga seotult tuleb regilauludest esile seega linnainimese vastuoluline kuvand: ühelt poolt viitab linn parematele elutingimustele (rikkus, mis võimaldab kergemat elu), teiselt poolt omistatakse linnaelule kõlvatute elu-

${ }^{16}$ H I 2, 685 (8); vrd EÜS X 1488 (41). Üldiselt väljendub „kauge” pigem maade kui linnade nimetustes. Näiteks kodust kaugele - Türgimaale /Saksamaale/Vene rajale - abiellunud tütart ei tunne kodused hiljem ära: E 6770 (24); E 15701 (206); E 33063 (2); kiik on toodud kaugelt - Türgimaalt / Saksamaalt, kusjuures kiigeosade loetelus kohtab värssi põhjalauad Põltsamaalt: E 36989 (1). Heaks kiidetakse kaugelt toodud road (soola toodud Soomemaalta,/rohud toodud Rootsimaalta, / petersellid Preisimaalta: H I 4, 211 (2)) ja kaugelt toodud naine (sa'i saa naista siita maalta, / sa tuod naise Narva maalta, / punapõlle Poolamaalta, / savipõlle Saksamaalta, / rohipõlle Rootsimaalta: H I 7, 419 (2)). 
kommete soodustamist. Ühtlasi joonistub välja sotsiaalne piir küla ja linna vahel: kaasavalikuga linnast ületatakse piir lähedase (tuttava, koduse) ja kauge (tundmatu, ettekujuteldava) vahel.

Linna kui „siit” (tuttavast, kodusest kohast) ära minekut esindavad ka nekrutilaulud. Nekrutilaulude peategelased satuvad linna, kus nende saatus on teadmata (ehk mind viiaks venelaseks); nende välimust muudetakse (pea piirati ja juuksed ära lõigati) ja tõdetakse: kuigi vanemad kasvatasid teda endile toeks, ei saa ta nekrutina nende ootusi enam täita [E 9006 (1); E 9079 (11); E 10013; E 26980 (13); E 38194]. Negatiivsele hoiakule vastandub bravuur: minnes linna, seatakse end sisse saksa viisi ja haritakse end härra viisi, visatakse viisud ja must kuub ahju [E 7667 (11)]. Nekrutilauludest võib leida kujuteldavaid linnapilte, kus on suur turg, lai loss; kus kõnnitakse vana linna valli pääl, uue linna uulitsal; või valvatakse linna müüri peal; viidatakse linna torni lippudele [E 7391; H I 5, 54 (108); E 29965; EÜS XI 229 (1)]. Erinevalt kosjateemalistest lauludest on nekrutilauludes seega sotsiaalse hoiaku asemel esil linnaruumi visuaalsus. Kuid ka nekrutilauludes eristab maad ja linna piir tuttava (omaks peetava) ja võõra vahel. Selle piiri kujutamisviiside tagapõhjaks on nekrutiks võetud noormehe rollimuutus. Nekrutilauludele on lähedased vangilaulud, kus kurja teinud tegelane viiakse linna kohtu ette või linna vangi torni [E 26311; H II 57, 352 (15)]. Selles kontekstis seostub linn riigitasandi instantsidega.

Maa ja linna omavahelist harjumuspärast seotust esindavad aga kaubandusteemaga laulud. Neis lauludes avaneb linn nii visuaalselt (laat, turg, tänavad, randuvad laevad) kui ka talupoja tegevuse kaudu (linna minek millegi müümiseks või ostmiseks). Tähelepanuväärne on, et linna ja kauplemise teema tuleb esile kosja- ja pulmalauludes, kus kaasa valitakse küll oma kodukohast, ent linnast tuuakse ehteid, riideid või muid kaupu. Linnast kauba toomist mainitakse muuhulgas ka kosjakommete kirjeldustes. Näiteks: „Üks nädal enne laulatamist sõidavad pruuti-peigmeest linna ehteid ostma" (H II 58, 671 (2) < Vändra, 1897). Sama kajastubki lauludes:

Ästi, ästi, peiukene, pruuti ootab kamberissa:

kasinast olid kaupa toonud, vähe sõrmuksid vedanud.

Kas olid lukus linna uksed

või pulgas poe väravad

või olid kambris kauba kirstud?

EÜS IX 703 (12) < Kuusalu - K. Viljak, G. Vilberg < Ann Einstruk (1912).

Mida linnast tuuakse? Üks levinumaid vormeleid selles kontekstis on linn - lint. Linnast võib linte tooma minna nii neiu kui ka noormees või neiu vanemad:

Ei ole neiduda kodugi, neid läks linnast linti tooma, alevista asjusiida, poest läks tooma puordisiida.

EÜS X 1715 (290) < Haljala - K. Viljak, J. Mark < Ann Sammelselg (1913). ${ }^{17}$

${ }^{17}$ Vrd H I 4, 799 (2); H I 5, 25 (43); E 15725 (256); E 35766 (29). 
Sama kujundit kasutatakse kirjeldamaks vaeslapse pulmi (talle jäid linnast lindid toomata) ja rahapuudust (külm võttis saagi ja ühtlasi ei saanud noormees saagi müügist oodatud raha) [H I 1, 225 (81); H I, 424 (9); EÜS VIII1158 (21)]. Kartus naisevõtu ees väljendub lauludes kujundis, kus naine ei ole nagu kaup, mida saab turul maha müüa (pole lehmaks linna viia) [H I 1, 75 (67); vrd EÜS VIII 1394 (100); H II 55, 452 (43)].

Tuleb esile, et linnast toodud riided (ehted) on ilusad ja külas hinnatud. See ilmneb näiteks lauludes, kus neidu või noormeest narritakse, kuna neil pole linnast toodud riideid ja vanemad lohutavad: toome linnast kauba [H I 1, 215 (62); H II 2 57, 622 (4); E 16088 (31); E 18017 (17)]. Samuti viitab poest ostetud riiete ilule värss meelepärast noormeest kirjeldavas motiivis (oleks see mees minule): vöö tal vööl kui linna linti [E 7186 (46); E 8403 (5); E 11799 (34); E 26147 (3)]. Või ka linna rihma [E 9339 (23); E 15599 (74); E 18893 (10); E 35758 (12); E 51093 (1); EÜS X 2633 (148)], linna lipu riie [H I 2, 686 (11)]; EÜS VIII 1409 (127)], linna lipukene (E 10990). Võrdluseks võib tuua, et vöö võib olla ka kui viiru vikerkaari [EÜS X 2072 (340)]. Et linn tundub uhkem, rikkam ja silmale enam pakkuvam kui küla, väljendub imeliku maja motiivis:

Kas on linna või on lippu

või on Soome soola laeva?

Mina mõistsin, neile kostsin:

See põle linna, see põle lippu, see põle Soome soola laeva.

See on sandi saunakene, vaese lapse peavarju.

E $3180<$ Põltsamaa - M. Kaur (1897).

Tervikut arvestades ilmneb muidugi, et see uhke, linnaks peetud koht on siiski külainimese elupaik.

Lõpetuseks vähestes lauludes esinevatest linnavärssidest. Esmalt võib leida viiteid linnale kadrilauludes, kus on juttu perenaise linna rätist ja katride teekonnast, mis viis läbi Lihula [E 18441 (1); EÜS VIII 1337 (12); EÜS VIII 2496 (11)]. Surmateemalises laulus tuuakse linnast sõel, et eemaldada haualt liiv [EÜS X 2722 (313)]. Neis näidetes lähtub kujutluspilt linnast seoses kaupade ja teekonnaga. Linn võib viidata ka kogukonnale, kui laulik suudab oma sõna võimu kasutades laulda linna (laada) vastu [E 8922 (1); E 11890 (3)]. Vähesel määral nähtub lauludest külast linna rände teema. Mõneti oli see teema juba jutuks linnast kaasavalikuga seoses, ent see tuleb esile ka iseseisvana, ainult tööga seoses. Linnatöid peetakse maatöödest kergemaks:

Lähme suveks Soomemaale, pooleks suveks Poolamaale, natukeseks Narva linna: seal põle heina niitemista ega loo võttemista.

E 23983 (2) < Ambla - J. Neublau (1896).

Harju-Jaani kihelkonnast üleskirjutatud lauludes kõneldakse otseselt linnarändest: 
Läksin Soome salaja,

läksin Rootsi redusse.

Soomes sain ma suureks meheks,

Rootsis sain ma rikkaks meheks.

Tulin Tallinna tagasi.

Kas see Tallinn tahab minda,

Tudulinna tunneb minda,

Võru linn mind võtab vasta?

Kui ei taha Tallinna

ega tunne Tudulinna,

Võru linn ei võta vasta -

kohe lähen Läti poole,

sammun jälle Soome poole,

varsti Vaasa linna poole.

H II 15, 662 (85) < Harju-Jaani - M. Neumann (1889).

Laulude kogumise kõrgajal, XIX sajandi lõpul, oli linnastumise ja rände teema tegelikus elus aktuaalne. Siis kasvasid Eesti linnad jõudsalt nii tööstuse arengu kui ka nt raudteeühenduste väljakujunemise tõttu. Samas muutus talude päriseksostmisega seoses peretüüp: laiendatud suurperedest eraldusid täiskasvanud õdede-vendade pered, kes pidid seni suguvõsa koos hoidnud majapidamistest omaette elama asuma (Palli 1998: 27). Sel ajal toimus ka väljaränne Eestist (peamiselt Venemaale), hõlmates 10-20 \% elanikkonnast (Rosenberg 1998: 36; 55). Muutused rahvastiku koosseisus ja inimeste seotuses oma põliskodudega ei kajastu neis lauludes siiski otsesõnu. Kui selle kohta mingeid hoiakuid ja kujutamisviise otsida, siis sisaldub see valdkond kaasavalikut kirjeldavates lauludes. Kuigi see teema on esitatud vastuoluliselt, on domineerivam hoiak see, et linna peetakse võõraks. Kaubandusteemaga on lood teisiti. Lisaks eeltoodud näidetele pöördun veel kord tagasi artikli alguses mainitud „Mareta lapse” laulu juurde, millest oli silma jäänud, et hüljatud lapse leidis linnateele läinud naine:

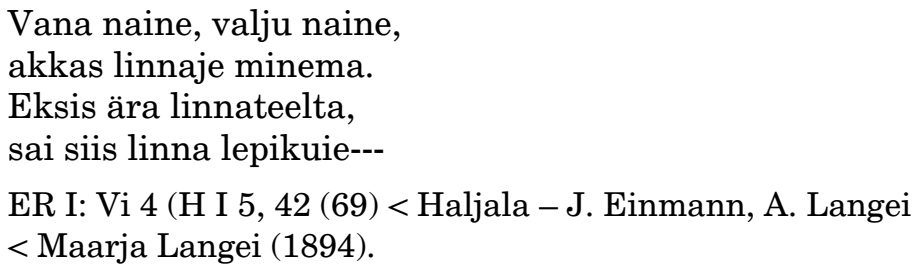

Lauluvariante lähemalt vaadeldes ilmneb, et selle laulu 36 üleskirjutusest leitakse laps linnateelt ainult seitsmes variandis, kusjuures see valik on koondunud Haljala lauludesse (Haljala seitsmest variandist leitakse laps linnateelt kuues tekstis), üks variant pärineb Amblast. Ometi on viiteid linnale selles laulus teisigi: et linna saksad kuulsid lapse nuttu [ER I: Vi 6 (H II 38, 140 (37) < Haljala)]; neiu, kes hüljatava lapse saab, läheb patuteele Riia rahad rindani [ER I: Vi 2 (H II 34, 324 (26) < Viru-Nigula)]; sündmus toimub linna lepikus [ER I: Vi 4 (H I 5, 42 (69) < Haljala)]. Kuigi on tegemist lokaalselt levinud kujundiga (või lokaalredaktsiooniga), võib siiski küsida, mil määral naised linnas käisid. Ajaloouurimustest ilmneb, et keskajal käisid naised linnas 
kaupa toomas: „Näiteks Tallinna kaupmehe Helmich Ficke arveraamatus on kirjas arvukalt talunaisi Jägalast ja Jõelähtmest. Ilmselt oli mõnikord talutöö seisukohalt otstarbekam, kui linna sõitis perenaine. On andmeid, et Tallinna turul kauples 16. sajandil hulgaliselt maanaisi" (EA II 2012: 200). Võib eeldada, et kaubandussuhted maa ja linna vahel toimisid regilaulutraditsiooniga paralleelselt pikemat aega, samal ajal kui nekrutiteema, eriti aga linnast kaasavalik ja linnarände teema olid XIX sajandi lõpul suhteliselt uued. Nii joonistub kaasavalik linnast välja pigem poleemilisena, suures osas vastanduvana tuttavale ja õigeks või normiks peetavale.

\section{Kokkuvõtteks}

Linnaga seotud kujundid jaotusid lähemal vaatlemisel kaheks: esmalt vormelitest lähtuvaks, seejärel linna ja maa omavahelise seose avamisest lähtuvaks. Kujundist ei ole põhjust otsida linnade kui geograafiliste paikade konkreetsust, ent linnanimesid sisaldavad sõnaseosed (alliteratsiooni- ja parallelismivormelid, paralleelsõnad) moodustavad teatavaid tähendusvälju, mis temaatiliselt koonduvad kirjeldama peamiselt kosjasid, kaubandussuhteid ja nekrutiks värbamist. Otsisõna „liina” abil kuvatud laulud jäid siinsest vaatlusest kõrvale, ent võrdluseks võib mainida, et kosjateema neis (peamiselt setu ja kaugueesti) lauludes samavõrra kui „linna” otsinuga kuvatud lauludes esile ei tule. Samas leidub „liina” sõna sisaldavaid värsse märkimisväärselt palju karjase- ja põlatud lapse teemalistes lauludes, nt karjalaps ajas karja ligi liina lepikusse; mine liina lepikude [vt nt H II 60, 223 (6); E 15753, E 18542 (15); EÜS IV 1305 (22)]. Kaubandus-, sõja-ja nekrutiteema on neiski lauludes linnakujunditega seotud.

Esmalt tuleb esile linna või linnanimedega seotud heakõlataotlus (Riia rikas, rist; Narva - naast, naine; Pärnu - pea, pärg, päev). Algriimuvad sõnad värsis ei pruugi lause seisukohalt sugugi olla põhi- ja täiendsõnad, näiteks alliteratsioonivormel on Peterburi - pikk; ent Peterburi sisaldavates värssides ühilduvad lause seisukohalt pikk tee, pikad püksid, pikk pool. Teiseks tuleb esile, et kordussõnade (ja ühtlasi paralleelvärsside) rohkus viitab kirjeldatava nähtuse või tegevuse mitmesuunalisusele, mis hajutab geograafilise konkreetsuse. Harvem võib aimata teatavat seost linnanimede valikul, näiteks paralleelvärssides esinevad kordussõnad Riia/Tallinn võivad kokku viia kubermangukeskused. Kolmandaks on märkimisväärne, et kordussõnade loendis on reeglina esiletulevamad ühendid (näiteks mainitud Riia- ja Narva-ühenditele lisaks Lihula linna; läbi Lihula). Neist on kujunenud vormelid, millele saab lisada analoogilisi sõnaseoseid. Teatud piirides tuleb ilmsiks, et linnanime kutsub esile hoopis teine sõna vormelis, seda näiteks kogukonnakujundites (naised-Narva / poisid-Poola).

Teemakeskse vaate puhul tuleb esile lauludes väljenduv suhtumine linna. Kui linn jääb nii-öelda „omale kohale” - seal käiakse ja sealt tullakse tagasi, siis ilmneb linna ja maa omavaheliste seoste neutraalsus, argielulisus ja loomulikkus. Nii on see linnast kauba toomise lugudes. Sotsiaalsete suhete muutumiste kirjeldustes omistatakse linnale kas külaga võrreldes paremaid omadusi (seal on kergem töö; parem elu; linnast saab head kaupa, ehteid ja ilusaid riideid) või vastupidi - linn esindab külaga võrreldes võorast, tundmatut maailma (moraalitu naine; nekrut; vangikong). Linnast kositud naine on üks 
vastuolulisemaid tegelasi regilauludes. Võib märgata suundumusi: kui värsis esineb sõna „linn”, siis on valdavalt (kuid mitte alati) tegemist probleemse naisevõtuga; sama kehtib ka siis, kui kasutatakse sõna Narva; teiste linnanimede (Helsingi, Piedari) kasutamisel eitav hoiak ei domineeri. Järeldub, et pikema aja vältel väljakujunenud suhted maa ja linna vahel kajastuvad regilaulus elu loomuliku osana. Elustiili muutustele viitavad seosed (linnastumine, nekrutiks värbamine) esitatakse aga poleemilisena.

Kui üldiselt esindavad laulud isiklikke ja kogukondlikke suhteid, siis nekruti- ja vangilauludes on linn seotud ka riigivõimuga. Reeglina ei seostu linn hariduse ega kultuuriga - see on peamiselt kauplemise koht, ometi on lauluoskus ja sõnavõim seostatav linnakujunditega: lauluhääl saadi Riias / Tallinnas ristimiselt; laulus sisalduva sõnavõimuga saadakse linna vastu.

Ühtlasi võimaldas pärimusliku ajaloo vaatepunkt lauluanalüüsis siduda omavahel mälu ulatuvusega seotud aspektid: traditsioonis pikema aja vältel väljakujunenud vormelikeele ja oma elukeskkonna kujutamisviisi (ehk laulus sisalduvad hoiakud ja mõttelaadi).

Artikkel seostub institutsionaalse uurimisprojektiga IUT2-43 ja Kultuuriteooria Tippkeskuse folkloristika uurimisrühma tegevusega, mida toetab Euroopa Liit Euroopa Regionaalarengu Fondi kaudu.

\section{E-andmebaasid}

Eesti Kirjandusmuuseum, Eesti Rahvaluule Arhiiv. Eesti regilaulude andmebaas: http://www.folklore.ee/regilaul

Rahvusarhiiv. Kinnistute register: http://www.eha.ee/labs/kinnistud

\section{Kirjandus}

B u r k e, Peter 2004. History and Folklore: A Historiographical Survey. - Folklore, nr 115 (2), lk 133-139.

D or s o n, Richard M. 1986. A Historical Theory for American Folklore. - Handbook of American Folklore. Toim Richard M. Dorson. Bloomington: Indiana University Press, lk 326-343.

EA 2012 = Eesti ajalugu II. Eesti keskaeg. Toim Anti Selart. Tartu: Tartu Ülikooli Ajaloo ja Arheoloogia Instituut.

E h i n, Kristiina 2003. Naise identiteedi muutus pärast Esimest maailmasõda rahvalaul kõneleb. - Pärimus ja tõlgendus. Artikleid folkloristika ja etnoloogia teooria, meetodite ja uurimispraktika alalt. Toim Tiiu Jaago. Tartu: Tartu Ülikooli Kirjastus, lk 158-172.

ER 1926 = Eesti rahvalaulud Dr. Jakob Hurda ja teiste kogudest I. Toim M. J. Eisen jt. Tartu: Eesti Kirjanduse Selts.

F o l e y, John Miles 1988. The Theory of Oral Composition: History and Methodology. Bloomington, Indianapolis: Indiana University Press.

H o p k i n, David 2004. Storytelling, fairytales and autobiography: some observations on eighteenth- and nineteenth-century French soldiers' and sailors' memoirs. - Social History, nr 29 (2), lk 186-198.

J a a g o, Tiiu 2006. Pärimusliku ajaloo uurimine. - Argikultuuri uurimise termi- 
noloogia e-sõnastik. Toim Tiiu Jaago. Tartu Ülikool, eesti ja võrdleva rahvaluule osakond (http://argikultuur.ut.ee).

K o k a m ä gi, Hilja, M ä lk, Vaina, R ü ü t e l, Ingrid, T a m p e r e, Herbert 1970. Priiusel' raiume rada ... Artiklite kogumik eesti revolutsioonilauludest. Tallinn: Eesti Raamat.

Ko l k, Udo 1962. Värsisisesed vormelid eesti regivärsilises rahvalaulus. - Tartu Riikliku Ülikooli toimetised, nr 117. Tartu: Tartu Riiklik Ülikool, lk 71-153.

L a u g a s t e, Eduard 1962. Eesti regivärsi struktuuriküsimusi. - Tartu Riikliku Ülikooli toimetised, nr 117. Tartu: Tartu Riiklik Ülikool, lk 25-70.

L i n t r o p, Aado 2006. Uhkest laevast Petropavlovskist, revolutsiooni kuulutajast. - Paar sammukest XXII. Eesti Kirjandusmuuseumi aastaraamat. Toim ErgoHart Västrik, Mall Hiiemäe. Tartu: Eesti Kirjandusmuuseum, lk 49-65.

L o r d, Albert B. 1997 [1960]. The Singer of Tales. Cambridge-London: Harvard University Press.

M i r o v, Ruth 1998. Regivärsilise ekspositsioonlauluga voormängud. Eesti Keele Instituudi Toimetised 2. Tallinn: Eesti Keele Instituut.

P alli, Heldur 1998. Eesti rahvastiku ajaloo lühiülevaade. Tallinn: Sisekaitseakadeemia.

P e e g e 1, Juhan 1997. Kuld on jäänud jälgedesse. Regivärsi keelest ja poeetikast. [Artikleid ja ettekandeid ajavahemikust 1955-1991.] Tartu: Eesti Kirjandusmuuseum.

R o s e n b e rg, Tiit 1998. Eestlaste väljaränne 19. sajandil - 20. sajandi algul: taust ja võrdlusjooni naabritega. - Eesti kultuur võõrsil. Loode-Venemaa ja Siberi asundused. Toim Astrid Tuisk. Tartu: Eesti Kirjandusmuuseum, lk 34-59.

R u b i n, David C. 1997. Memory in Oral Traditions: The Cognitive Psychology of Epic, Ballads, and Counting-out Rhymes. New York-Oxford: Oxford University Press.

R ü ü t e l, Ingrid 1977. 1877.-1878. a. Vene-Türgi sõda eesti laulutraditsioonis. Keel ja Kirjandus, nr 8, lk 481-488; nr 9, lk 550-555.

S a a r l o, Liina 2001. Regilaulude vormelid: kvantiteet ja kvaliteet. - Regilaul keel, muusika, poeetika. Toim Tiiu Jaago, Mari Sarv. Tartu: Eesti Kirjandusmuuseum, lk 271-297.

S a r v, Mari 2000. Regilaul kui poeetiline süsteem. - Paar sammukest XVII. Eesti Kirjandusmuuseumi aastaraamat. Toim Janika Oras, Ergo-Hart Västrik. Tartu: Eesti Kirjandusmuuseum, lk 7-122.

S c ollo n, Ron, Sc ollon, Suzanne 1995. Somatic Communication: How Useful is 'Orality' for the Characterization of Speech and Cultures? - Aspects of Oral Communication. Toim Uta M. Quasthoff. Berlin-New York: Walter de Gruyter, lk 19-29.

T a m p e r e, Herbert 1958. Eesti rahvalaule viisidega III. Tallinn: Eesti Riiklik Kirjastus.

T e d r e, Ülo 1964. Tähelepanekuid regivärsilise rahvalaulu tüpoloogiast. - Eesti rahvaluulest. Toim Veera Pino, Ülo Tedre, Richard Viidalepp. Tallinn: ENSV Teaduste Akadeemia, lk 7-34.

T e d r e, Ülo 2003 [1954]. Eesti mees ja tema sugu. XIX sajandi Eesti lõppriimilises rahvalaulus. Tallinn-Tartu: Eesti Kirjandusmuuseum.

T e d r e, Ülo 2008 [1998]. Rahvaluule. - Eesti rahvakultuur. Toim Ants Viires, Elle Vunder. Tallinn: Eesti Entsüklopeediakirjastus, lk 423-448.

T i t o n, Jeff Todd 1980. The Life Story. - The Journal of American Folklore, nr 93 (369), lk 276-292. 


\section{Urban themes in older Estonian folk song (regilaul)}

Keywords: urban topic in folk song, research of regilaul, formula, stereotypism

Usually urban themes are not to be anticipated in older Estonian folk song.This is, firstly, because the songs presumably date back to more than two thousand years. Secondly, the background and typical themes refer regilaul to an agrarian culture. The tradition of singing in regilaul style receded from active use after the mid19 th century, with the advance of extensive changes in the economy, education and population behaviour in the present-day Estonian territory. At a closer look, however, some figures involving town names as well as mentions of urban themes can be observed. In Estonia, the first townships emerged in the 13th and 14th centuries, developing into towns in the Late Middle Ages. For village people a town meant, first and foremost, a trading place. Etymologically the Estonian word linn 'town, city' refers to a stronghold or citadel, which is also manifested in the songs where 'town' is associated with 'stronghold', metaphorically referring to protection of parents and family. The article analyses the town names and urban themes occurring in regilaul. The approach is based on social history, asking to what extent the songs might reveal the everyday life and attitudes of the villagers of the time. The first part of the study is focused on formulas, i.e. on alliterative phrases, where a town name is included, e.g. Riia - rikas 'rich'; rist 'cross'; Narva - naine 'woman, wife' ; Lihula - linna 'citadel'. The second part analyses the townbound attitudes manifested in the songs. There are three major urban themes: the rituals and procedures leading to a marriage proposal, trade, and recruitment of soldiers. Migration from villages to towns is less elaborated. In most cases it has to do with job search, while urban work and lifestyle are considered easier than the rural ones. A wife wedded from town is a theme arousing markedly contradictory attitudes, but the image of the town woman as one with low morals is dominating. Bringing down goods from the town, however, was usual and town goods were appreciated.

Tiiu Jaago (b. 1960), PhD, University of Tartu, docent of folklore, tiiu.jaago@ut.ee 